\title{
Economic efficiency and productivity of lifting and distribution methods of groundwater for wheat and tomato in New Valley governorate
}

\author{
Hani El-Shatla', Eman A. Ahmed ${ }^{2}$, Reda Essa ${ }^{3 *}$ (D) and Manal F. Mohamed ${ }^{3}$
}

\begin{abstract}
Background: This research was aimed to study the structure of actual investment costs and operating and maintenance costs for raising and distributing ground water through the use of different irrigation methods and for estimating the most important economic and technical indicators for raising and distributing groundwater for the most important agricultural crops in Wadi El-Gadid (New Valley province).

Methods: This work was based on secondary data issued by the Ministry of Agriculture and Land Reclamation and field data obtained through personal interviews of wheat and tomato farmers by irrigation method (spray, flooding, and the method of lifting and distribution of water in the case of the use of diesel and conveyor belts), and the use of electricity and deep pumps, through the questionnaire design. A sample of 40 farmers was used.
\end{abstract}

Results: The results showed that the productivity and economic efficiency indicators for the lifting and distribution of groundwater by a power source during the agricultural season 2017/2018 increased the average productivity of total yield, net revenue/fed., net return/pound, and irrigation water in both crops.

Conclusion: The results showed that the method of lifting and distribution of water is more efficient than irrigation by flooding.

Keywords: Ground pipes, Groundwater, Spray irrigation, Flooding irrigation

\section{Introduction}

The issue of water and achieving economic efficiency for the use of irrigation water is one of the most important contemporary and future issues of Egyptian agriculture, and the issue of food security increasing and to increase the conviction that policies for the management and use of these resources needs to be revised and reworked as one of the main trends in increasing production and productivity (Osama 2005).

Sustainable agricultural development programs require the implementation of agricultural expansion projects both vertical and horizontal under more efficient water rates and more effective practices in the exploitation of limited water and area. Therefore, the achievement of

\footnotetext{
* Correspondence: mashrera@yahoo.com

${ }^{3}$ Field Crops Res. Department, NRC, Dokki, Giza, Egypt

Full list of author information is available at the end of the article
}

these objectives depends on the availability of water for irrigation at the desired location and the appropriate timing with appropriate quantities and types, in an appropriate economic and environmental framework where the problem is the limited water resources and not using it better. So, we must make maximum benefit of the available water (Heba 2008).

The State has given great importance to the horizontal expansion of new and desert lands in the light of the limited land resources used in agriculture. Therefore, it has been concerned with the policy of land reclamation to increase agricultural land. Therefore, the aim of agricultural planning at the national or partial level is to distribute available economic resources in order to arrive to an appropriate economic use of these resources in the circumstances and possibilities available in society and to reach a pattern of economic use for these resources 
under the conditions and possibilities available in society (Mohamed et al. 2018).

The New Valley province was chosen as the place to conduct the study as it is one of the most promising desert border provinces. It is located in southwestern Egypt and shares its borders with the Giza province and Marsa Matrouh province in the north. Also, the other provinces in the east of the New Valley province are Minya, Assiut, and Qena, with an area of about 440 thousand $\mathrm{km}^{2}$ equivalent to about $44 \%$ of Egypt's area (Hani and Salah 2013).

Groundwater is the main source of irrigation for agricultural crops and is dependent on horizontal agricultural expansion. Many studies indicate that the groundwater reserves in this governorate are estimated at 78 thousand billion $\mathrm{m}^{3}$ and an annual feed rate of 584 million $\mathrm{m}^{3} /$ year; the estimated amount of water available from $150 \mathrm{~m}$ of Nubian sandstone was estimated at 234 billion $\mathrm{m}^{3}$, and this quantity, along with the annual feeding, can be used to irrigate 5000.000 fed. for an estimated period of 700 years (Jalal 2003).

Several studies have shown that there are around 55 thousand billion $\mathrm{m}^{3}$ of underground water. However, due to economic considerations, this quantity cannot be exploited. Therefore, the economically exploited quantities are only about 15 thousand billion $\mathrm{m}^{3}$ (Abdul Majid 2018).

\section{Research problem}

The pattern of groundwater use is affected by irrigation method (traditional and unconventional) and the method of raising and distributing water in New Valley governorate on the amount of water used, then the cost of using them, and therefore the amount of production and income from agricultural crops, which requires the study of the efficiency indicators of these different types.

\section{Aim of the research}

The aim of the research was to identify the patterns of lifting and distribution of groundwater in New Valley governorate by studying the structure of actual investment costs and operating and maintenance costs to raise and distribute these water through the use of different irrigation methods and to estimate the actual costs of raising water and irrigation using the most important economic and technical indicators for wheat and tomato crops.

\section{Materials and methods}

The research depended on two types of data first. The first type was the secondary data issued by the Ministry of Agriculture and Land Reclamation. The second type was from the field data obtained through personal interviews of wheat and tomato farmers by irrigation method using the questionnaire which included all the variables.
A sample of 40 farmers distributed evenly between the two methods of raising and distributing water for both crops according to irrigation method was chosen.

\section{Results \\ Methods of lifting and distribution of groundwater}

The different methods used in raising and using under groundwater in New Valley are different. This difference is mainly due to the different material resources and different equipment of the farmers. There are several types of plantations in the governorate, including the type of farms that use vertical lifting pumps. It is usually used to transport traffic from its source to the pump, as it is directly connected to the transmission shaft. Therefore, it does not need to be built on the ground directly. It is characterized by the absence of a missing capacity during the transmission and the reduction of fuel losses.

The second type is the construction of a park and getting off the water lifting pump at depths ranging from 15 to $25 \mathrm{~m}$ below the surface of the earth until reaching the groundwater. The movement is transferred from the motor to the pump using the belts and the planes. It is characteristic that it does not require technical labor. The third type is the use of electricity as an energy source to raise the water and the use of deep pumps.

\section{The relative importance of the structure of investment costs}

The results indicated in Table 1 show the relative importance of the investment costs required to raise the groundwater by power source in New Valley governorate during the 2017/2018 agricultural season. It has been shown that the investment costs include the cost of motor and lifting equipment and pipes. Its cost in the case of diesel and conveyor belts is about 11.93, 6.33, and 6.12 thousand pounds, representing about $48.94 \%$, $25.96 \%$, and $25.10 \%$, respectively, of the total investment costs of about LE 24.29 thousand.

In the case of the use of electricity and deep water pumps, it amounted to about 36.7, 3.26, and 3.31 thousand pounds, representing $84.1 \%, 7.54 \%$, and $7.65 \%$, respectively, of the total investment costs of about 43.28 thousand pounds. From the above statement, it is clear that the costs of motor and lifting equipment represent the most important items of investment costs necessary for the pumping of groundwater in New Valley, which requires shedding light on those items in some detail as follows.

\section{Motor and lifting equipment}

The cost of purchasing and transporting the pump, motor, pump chassis, motor chassis, diesel, transmission, electricity, and deep pumps is added to the previous costs in the case of diesel and conveyor belts. In the case 
Table 1 The relative importance of investment costs required to raise groundwater by source of capacity in New Valley governorate during season 2017/2018

\begin{tabular}{|c|c|c|c|c|c|c|c|}
\hline \multirow[t]{2}{*}{ Power source } & \multirow[t]{2}{*}{ Statement } & \multicolumn{3}{|c|}{ Use of electricity and deep pumps } & \multicolumn{3}{|c|}{ Use of diesel and conveyor belts } \\
\hline & & LE & $\begin{array}{l}\text { Main items } \\
(\%)\end{array}$ & $\begin{array}{l}\text { Sub-items } \\
(\%)\end{array}$ & LE & $\begin{array}{l}\text { Main items } \\
(\%)\end{array}$ & $\begin{array}{l}\text { Sub-items } \\
(\%)\end{array}$ \\
\hline \multirow{8}{*}{$\begin{array}{l}\text { Motor and lifting } \\
\text { equipment }\end{array}$} & Price of buying and transporting pump & 3240.00 & 13.29 & 27.15 & 4266.00 & 9.85 & 11.62 \\
\hline & Price of buying and moving motor & 7128.00 & 29.23 & 59.73 & 4071.60 & 9.42 & 11.09 \\
\hline & Cost of pump chassis & 432.00 & 1.77 & 3.62 & 518.40 & 1.20 & 1.42 \\
\hline & Cost of motor chassis & 378.00 & 1.55 & 3.17 & 432.00 & 0.99 & 1.18 \\
\hline & Cost of tires & 410.00 & 1.68 & 3.43 & 0.00 & 0.00 & 0.00 \\
\hline & Cost of belts & 345.6. & 1.42 & 2.90 & 0.00 & 0.00 & 0.00 \\
\hline & Price of converter and components & 0.00 & 0.00 & 0.00 & 27413.96 & 63.35 & 74.69 \\
\hline & $\begin{array}{l}\text { Total value of motor and lifting } \\
\text { equipment }\end{array}$ & 11934.00 & 48.94 & 100.00 & 36701.96 & 84.81 & 100.00 \\
\hline \multirow[t]{7}{*}{ Harpoons and pipes } & Price of ground pipes & 3066.12 & 12.57 & 48.41 & 2700.00 & 6.24 & 82.78 \\
\hline & Price of pumping tubes & 561.60 & 2.30 & 8.87 & 561.6 & 1.30 & 17.22 \\
\hline & Cost of installing pipes & 1782.00 & 7.31 & 28.14 & 8.00 & 0.00 & 0.00 \\
\hline & Cost chiming & 237.60 & 0.97 & 3.75 & 0.00 & 0.00 & 0.00 \\
\hline & Cost of packaging & 410.40 & 1.68 & 6.48 & 0.00 & 0.00 & 0.00 \\
\hline & Cost of salinity tests & 275.40 & 1.13 & 4.35 & 0.00 & 0.00 & 0.00 \\
\hline & Total value of pipes & 6333.12 & 25.96 & 100.00 & 3261.6 & 7.54 & 100.00 \\
\hline \multirow[t]{5}{*}{ Buildings } & Cost of ground & 2160.00 & 8.68 & 35.29 & 1188.00 & 2.74 & 35.87 \\
\hline & Cost of building Bayyara & 2718.36 & 11.15 & 44.42 & 0.00 & 0.00 & 0.00 \\
\hline & Cost of motor room & 918.00 & 3.76 & 15.00 & 1800.40 & 4.16 & 54.35 \\
\hline & Cost of distribution basin & 324.00 & 1.33 & 5.29 & 324.00 & 0.75 & 9.78 \\
\hline & Total value of building Bayyara & 6120.36 & 25.10 & 100.00 & 3312.04 & 7.65 & 100.00 \\
\hline Total of investment costs & & 24387.48 & 100.00 & 0.00 & 43275.56 & 100.00 & - \\
\hline
\end{tabular}

Source: Ministry of Agriculture and Land Reclamation, Economic Affairs Sector, unpublished data

Table 2 The relative importance of annual operation and maintenance costs of well of raising the groundwater by the source of capacity in New Valley governorate during season 2017/2018

\begin{tabular}{|c|c|c|c|c|c|c|c|}
\hline \multirow[t]{2}{*}{ Power source } & \multirow[t]{2}{*}{ Statement } & \multicolumn{3}{|c|}{ Use of electricity and deep pumps } & \multicolumn{3}{|c|}{ Use of diesel and conveyor belts } \\
\hline & & $\mathrm{LE}$ & $\begin{array}{l}\text { Main items } \\
(\%)\end{array}$ & $\begin{array}{l}\text { Sub-items } \\
(\%)\end{array}$ & $\overline{\mathrm{LE}}$ & $\begin{array}{l}\text { Main items } \\
(\%)\end{array}$ & $\begin{array}{l}\text { Sub-items } \\
(\%)\end{array}$ \\
\hline \multirow[t]{5}{*}{ Fuel and maintenance } & Fuel & 4898.88 & 34.10 & 68.80 & 6026.40 & 40.00 & 70.30 \\
\hline & Motor maintenance & 731.380 & 5.10 & 10.30 & 1298.27 & 8.60 & 15.10 \\
\hline & Repair & 1060.60 & 7.40 & 14.90 & 1252.8 & 8.30 & 14.60 \\
\hline & Maintenance of belts and tires & 432.00 & 3.00 & 6.00 & 0.00 & 0.00 & 0.00 \\
\hline & Total fuel and maintenance & 7122.86 & 49.60 & 100.00 & 8577.47 & 57.00 & 100.00 \\
\hline \multirow[t]{3}{*}{ Employment } & Sustainable & 3628.80 & 25.30 & 93.30 & 3888.00 & 25.80 & 73.20 \\
\hline & Artistic & 259.20 & 1.80 & 6.70 & 1422.79 & 9.40 & 26.80 \\
\hline & Total employment & 3888.00 & 27.10 & 100.00 & 5310.79 & 35.30 & 100.00 \\
\hline \multirow[t]{4}{*}{ Oils and lubricants } & Value of oils & 1728.00 & 12.00 & 51.60 & 0.00 & 0.00 & 0.00 \\
\hline & Diesel and oil filters & 972.00 & 6.80 & 29.10 & 864.00 & 5.70 & 73.90 \\
\hline & Greases & 648.00 & 4.50 & 19.30 & 305.10 & 2.00 & 26.10 \\
\hline & Total oils and lubricants & 3348.00 & 23.30 & 100.00 & 1169.10 & 7.80 & 100.00 \\
\hline \multicolumn{2}{|c|}{ Total operating and maintenance costs } & 14358.80 & 100.00 & 0.00 & 15057.00 & 100.00 & 0.00 \\
\hline
\end{tabular}


of the use of electricity and deep water pumps, the price of the transformer and its components were added. The cost of diesel and conveyor belts was 3.24, 7.13, 0.43, $0.38,0.41$, and 0.35 thousand pounds, representing about $13.29 \%, 29.23 \%, 1.77 \%, 1.55 \%$, and $1.42 \%$, respectively, out of the total investment costs amounting to LE 24.39 thousand.

Representing about 27.15\%, 59.73\%, 3.62\%, 3.17\%, $3.43 \%$, and $2.9 \%$ of the total cost of buying motor and lifting equipment, it is amounting to about 11.93 thousand pounds. The total value of the total investment costs of about $43.88 \%$ was $0.22 \%, 0.92 \%, 0.34 \%$, and $0.35 \%$, respectively, fairly. Representing $11.62 \%, 11.09 \%$, $1.42 \%, 1.18 \%$, and $4.69 \%$ of the total cost of the purchase of motor and lifting equipment, it is amounting to about 36.70 thousand pounds. In the case of the use of electricity and deep water pumps, the price and components of the transformers are included in the top of these items. The total cost of the motor and lifting equipment in the case of the use of electricity and deep water pumps are three times the cost in the case of the use of diesel and conveyor belts, mainly due to the higher cost of purchasing the transformer and its components.

\section{Pipes and war}

It includes the cost of ground pipes and discharge pipes in the case of the use of diesel, transmission belts, and electricity and deep pumps, in addition to the previous costs in the case of the use of diesel and transmission belts and the cost of each of the pipes, warp, warp wire, and salinity tests. The relative importance of the previous items indicates that their cost in the case of diesel and conveyor belts reached $3.10 \%, 0.56,1.78,0.24,0.41$, and 0.28 thousand, representing about $12.60 \%, 2.30 \%$, $7.30 \%, 0.97 \%$, and $1.68 \%$, respectively, out of the total investment costs amounting to LE 24.39 thousand. About $48.40 \%, 8.87 \%, 28.10 \%, 3.75 \%, 6.48 \%$, and $4.35 \%$ of the total cost of buying pipes and war is amounting to about 6.33 thousand pounds.

It was about LE 2.56 thousand in the case of the use of electricity and deep pumps, representing about $6.24 \%$ and $1.30 \%$ respectively of the total of the total investment costs of about 43.28 thousand pounds, representing about $82.78 \%$ and $17.22 \%$ of the total cost of buying pipes and war, and amounting to about 3.26 thousand pounds. It is also clear that while the top of these items is the cost of ground pipes in the case of the use of diesel and conveyor belts, the case of the use of electricity and deep pumps are also in the forefront and the total cost of pipes and war in the case of the use of electricity and pumps of the depths equivalent to about half of the cost in the case of the use of diesel and conveyor belts, mainly because the latter system requires more technical operations and at a greater cost such as pipe knock and warp and warp wire and salinity tests.

\section{Buildings the well}

The relative importance of the items, the cost of the ground, the building of the well, the motor room, and the distribution basin, indicates that the cost of diesel and conveyor belts reached 2.16, 2.72, 0.92, and 0.32 thousand pounds, representing 8.86\%, 11.15\%, 3.76\%, and $1.33 \%$ respectively of the total investment costs amounting to about 24.39 thousand pounds. Representing about $35.29 \%, 44.42 \%, 15 \%$, and $5.29 \%$ of the total cost of construction, it is amounting to about 6.12 thousand pounds. In the case of the use of electricity and deep water pumps, the cost includes the cost of the lighting floor, the motor room, and the distribution basin, and the relative importance of the previous items shows that the cost was about 11.88, 1.80, and 0.32 thousand pounds, representing about $2.74 \%, 4.16 \%$, and $0.75 \%$ of the total investment costs of about 43.28 thousand pounds.

Representing $35.87 \%, 54.35 \%$, and $9.78 \%$ of the total cost of buildings and buildings, it amounted to about 3.31 thousand pounds in the case of the use of electricity and deep water pumps. The cost of the motor room is at the top. The total cost of the all well buildings in the case of the use of electricity and deep water pumps is compared to $54.12 \%$ of the same in the case of the use of diesel and conveyor belts, mainly because the latter system does not require the cost of construction of the building, and finally, in general, the total investment costs in the case of the use of electricity and deep pumps are equivalent to about 1.77 times compared to diesel machine use and transfer conveyor movement, due to the significant rise in the price of electrical transformer and all accessories.

\section{Relative importance of operating and maintenance cost structure}

The results in Table 1 show the relative importance of the operational and maintenance cost structure required for groundwater recharge according to the source of capacity in New Valley governorate during the $2017 / 2018$ agricultural season. It was found that the operation and maintenance costs include the cost of fuel and maintenance, human labor, oils, and lubricants, and the cost of diesel and conveyor belts reached $7.12,3.89$, and 3.35 thousand pounds, accounting for $49.60 \%, 27.10 \%$, and $23.30 \%$, respectively, of total operating and maintenance costs, amounting to LE 14.40 thousand. In the case of the use of electricity and deep pumps, it is about $57 \%$, $35.3 \%$, and $7.8 \%$ respectively of the total operating and maintenance costs of about LE 15.06 thousand. 
From the above statement, it is clear that a fuel and maintenance cost represents the most important items of the annual operating.

\section{Fuel and maintenance}

It includes the cost of fuel, motor maintenance, repair in the case of diesel use and conveyor belts and transmission belts, and electricity and pumps depths, in addition to the previous costs in the case of the use of diesel and conveyor maintenance of the belt and the cost. In the case of diesel and conveyor belts, as follows, 0.73, 1.06, and 0.43 thousand pounds, it is representing about $34.10 \%, 5.10 \%, 7.40 \%$, and $3.00 \%$ respectively of the total operating and maintenance costs of about LE 14.36 thousand and about $68.8 \%, 10.30 \%, 14.90 \%$, and $6.10 \%$ of the total cost of fuel and maintenance, amounting to about 7.12 thousand pounds (about LE 6.03, 1.30 and 1.26 thousand).

In the case of electricity and deep water pumps, it is about $40.00 \%, 8.60 \%$, and $8.30 \%$ respectively of the total operating and maintenance costs of about LE 15.10 thousand, and it is about $70.30 \%, 15.10 \%$, and $14.60 \%$ of the total cost of fuel and maintenance of about 8.60 thousand pounds. The cost of fuel in the case of the use of diesel and conveyor belts is also at the top of the cost items in the case of the use of electricity and deep water pumps. The total cost of fuel and maintenance in the case of the use of electricity and deep water pumps is 1.20 times such as the use of diesel and conveyor belts, mainly due to the higher cost of all items in the case of the use of electricity and deep pumps compared to the case of diesel and transmission belts.

\section{Human work}

These include the cost of permanent labor and technical labor. The cost of using diesel and conveyor belts is about 3.63 and 0.56 thousand pounds, and these include the cost of permanent labor and technical labor. So, the cost if we are using diesel and conveyor belts is about 3.63 and 0.56 thousand pounds, representing about $25.30 \%$ and $1.80 \%$ of the total operating and maintenance costs of about LE 14.36 thousand accounting for $93.30 \%$ and $6.70 \%$ of the total labor cost of about 3.89 thousand pounds.

It was about 3.89 thousand pounds and 1.42 thousand pounds in the case of the use of electricity and deep pumps, representing about $25.80 \%$ and $9.40 \%$ respectively of the total operating and maintenance costs of about 15.10 thousand pounds. It is representing about $73.20 \%$ and $26.80 \%$ of the total labor cost, which amounted to about 5.31 thousand pounds. From the above statement, it is clear that these items are the costs of permanent employment in the case of the use of diesel and conveyor belts come first; otherwise, the case of the use of electricity and deep pumps also comes in the forefront as that the total cost of human labor in the case of the use of electricity and the depth pumps is equivalent to about 1.37 times the same as in the case of the use of diesel and transmission; mainly, this is primarily due to the fact that the first system needs more technical labor at greater cost in operations.

\section{Oils and lubricants}

These include the cost of lubricants, diesel, and oil filters in the case of diesel, transmission, electricity transmission lines, electricity, and deep water pumps, in addition to the previous costs in the case of the use of diesel and conveyor belts; the cost of oil and the relative importance of the previous items indicate that the cost in the case of the use of diesel and conveyor belts amounted to about $1.73,0.97$, and 0.65 thousand pounds, representing about $12.00 \%, 6.80 \%$, and $4.50 \%$. The order of the total of the general total of operating and maintenance costs is amounting to about LE 14.36 thousand, representing about $51.60 \%, 29.10 \%$, and $19.30 \%$ of the total cost of oils and lubricants, amounting to about 3.35 thousand pounds. It was about 0.86 and 0.31 thousand pounds in the case of the use of electricity and deep pumps, representing about $5.7 \%$ and $2 \%$ respectively of the total of the total operating and maintenance costs of about 15.10 thousand pounds and accounted for $73.90 \%$ and $26.10 \%$ of the total cost of oils and lubricants, amounting to about 1.17 thousand pounds.

It is also clear that while the top of these items is the cost of oil in the case of the use of diesel and conveyor belts, the case of the use of electricity and deep pumps comes in the forefront of the cost of diesel filters and oil and the total cost of oils and lubricants in the case of the use of electricity and pumps. The depth is equivalent to 0.35 of the same in the case of the use of diesel and conveyor belts, mainly due to the lack of electricity to use the oil in abundance, and, in general, the overall operation and maintenance costs in the case of the use of electricity and deep pumps is equivalent to about 1.05 times the same as the case of the use of diesel and conveyor belts.

\section{Actual costs of groundwater recharge}

The data and results presented in Table 3 refer to the structure of the cost of raising the thousand cubic meters of groundwater in New Valley governorate during the agricultural season $2017 / 2018$. It is clear that this cost includes the cost of capital depreciation, return on capital, from the source of capacity to the other, where the value is about $1.91,0.62$, and 14.40 thousand pounds, representing about $11.30 \%, 3.70 \%$, and $85.00 \%$ respectively of the total actual costs in the case of the use of diesel and conveyor belts amounting to about 
Table 3 The cost of raising thousand cubic meters of groundwater in New Valley governorate during season 2017/2018

\begin{tabular}{|c|c|c|c|c|c|c|c|}
\hline \multirow[t]{2}{*}{ Power source } & \multirow[t]{2}{*}{ Statement } & \multicolumn{3}{|c|}{ Use of electricity and deep pumps } & \multicolumn{3}{|c|}{ Use of diesel and conveyor belts } \\
\hline & & $\mathrm{LE}$ & $\begin{array}{l}\text { Life } \\
\text { expectancy }\end{array}$ & $\begin{array}{l}\text { Depreciation } \\
\text { premium }\end{array}$ & $\overline{\mathrm{LE}}$ & $\begin{array}{l}\text { Life } \\
\text { expectancy }\end{array}$ & $\begin{array}{l}\text { Depreciation } \\
\text { premium }\end{array}$ \\
\hline \multirow[t]{6}{*}{ Investment costs } & Motor and lifting equipment & 11934.00 & 10.00 & 1193.40 & 367.20 & 10.00 & 3670.002 \\
\hline & Towing and lifting pipes & 6057.72 & 15.00 & 403.805 & 3261.60 & 15.00 & 217.44 \\
\hline & Bayyara pipes & 5796.36 & 20.00 & 289.802 & 2988.40 & 20.00 & 149.42 \\
\hline & Distribution basin & 324.00 & 15.00 & 21.60 & 324.00 & 15.00 & 21.60 \\
\hline & Total capital depreciation & & & 1908.70 & & & 1095.60 \\
\hline & Return on capital & & & 617.40 & & & 6026.40 \\
\hline \multirow{5}{*}{$\begin{array}{l}\text { Operating and } \\
\text { maintenance costs }\end{array}$} & Fuel & & & 4898.88 & & & 6026.40 \\
\hline & $\begin{array}{l}\text { Maintenance of motors, pumps, } \\
\text { belts, and tires }\end{array}$ & & & 2223.98 & & & 2551.07 \\
\hline & $\begin{array}{l}\text { Sustainable and technical labor } \\
\text { wages }\end{array}$ & & & 3888.00 & & & 5310.79 \\
\hline & Oils, filters and lubricants & & & 3348.00 & & & 1169.10 \\
\hline & $\begin{array}{l}\text { Total operating and maintenance } \\
\text { costs }\end{array}$ & & & 14358.80 & & & 15057.40 \\
\hline \multicolumn{2}{|l|}{ Total actual costs } & & & 16884.90 & & & 20211.70 \\
\hline \multicolumn{2}{|c|}{ Disposal of water a thousand $\mathrm{m}^{3} /$ year } & & & 128.79 & & & 128.79 \\
\hline \multicolumn{2}{|c|}{ Cost of raising a thousand cubic meters of water in pounds } & & & 131.10 & & & 156.94 \\
\hline
\end{tabular}

Source: Ministry of Agriculture and Land Reclamation, Economic Affairs Sector, unpublished data

Osama Mahmoud Aweida, economic efficiency of the methods of lifting and distribution of groundwater in the new land in Egypt, reference above

Return on capital = (total investment costs price, interest rate on the loan 22) to estimate the interest rate for the first and last term, and the interest rate announced by the Central Bank of Egypt in 2017 was 19.75

Water disposal A m $3 /$ year $=540 \mathrm{~h}$ operating $\times 238.5 \mathrm{~m}^{3} / \mathrm{h}=128.79 \mathrm{~m}^{3} /$ year

Water disposal $\mathrm{A} \mathrm{m}^{3} /$ year/cost of raising a thousand cubic meters of water $=$ total. Source: Ministry of Agriculture and Land Reclamation, Economic Affairs Sector, unpublished data. Actual costs and maintenance costs required for the pumping of groundwater in New Valley governorate which requires shedding light on those items in some detail as follows

Table 4 Relative Importance of costs of raising and distribution of groundwater for field sample field crops by source of capacity in New Valley governorate during season 2017/2018

\begin{tabular}{|c|c|c|c|c|c|}
\hline \multirow[t]{2}{*}{ Statement } & \multirow[t]{2}{*}{ Unit } & \multicolumn{2}{|l|}{ Tomatoes } & \multicolumn{2}{|l|}{ Wheat } \\
\hline & & Flooding irrigation & Spray irrigation & Flooding irrigation & Spray irrigation \\
\hline Quantity of irrigation water & Thousand $\mathrm{m}^{3} / \mathrm{fed}$ & 5.49 & 4.25 & 3.52 & 2.08 \\
\hline Cost of raising water by diesel & Pounds $/ \mathrm{m}^{3}$ & 131.10 & 131.10 & 131.10 & 131.10 \\
\hline Cost of raising water by electricity & Pounds $/ \mathrm{m}^{3}$ & 156.90 & 156.90 & 156.90 & 156.90 \\
\hline Cost of raising water by diesel & Pounds/acres & 719.70 & 557.20 & 461.50 & 272.70 \\
\hline Relative importance & $\%$ & 8.99 & 5.53 & 55.71 & 36.93 \\
\hline Cost of raising water by electricity & Pounds/acres & 861.40 & 666.80 & 552.30 & 326.40 \\
\hline Relative importance & $\%$ & 10.76 & 6.62 & 66.67 & 44.19 \\
\hline Variable cost by diesel & Pounds/acres & 8726.00 & 10637.00 & 1290.00 & 1011.00 \\
\hline Variable cost by diesel & Pounds/acres & 8867.00 & 10747.00 & 1381.00 & 1065.00 \\
\hline Fixed costs & Thousand $\mathrm{m}^{3} / \mathrm{fed}$ & 2386.00 & 2386.00 & 1996.00 & 2195.00 \\
\hline Total diesel costs & Pounds/m3 & 11111.00 & 13023.00 & 3286.00 & 3206.00 \\
\hline Total costs & Pounds/acres & 11253.00 & 13133.00 & 3376.00 & 3260.00 \\
\hline
\end{tabular}

Source: collected and calculated from the questionnaire data for the agricultural season 2017/2018 
16.90 thousand pounds. It amounted to $4.10,1.10$, and 15.10 thousand pounds, representing about $20.10 \%$, $5.40 \%$, and $74.50 \%$ respectively of the total actual costs in the case of the use of electricity and deep pumps, amounting to about 20.20 thousand pounds.

It is also clear that while the top of these items is the cost of operation and maintenance in the case of the use of diesel and conveyor belts, in the case of the use of electricity and deep pumps are also in the forefront, and the total actual cost in the case of the use of electricity and deep pumps is equivalent to 1.20 times in the case of the use of diesel and conveyor belts. As a result, the annual disposal of irrigation water for the two plants has become stable. The cost of raising the millimeter of irrigation water is about 131.10 and 156.90 pounds for the two types of power supply in the case of diesel and electricity respectively.

\section{The relative importance of irrigation costs}

The results shown in Table 4 are the relative importance of irrigation costs of groundwater by power source in New Valley governorate during the agricultural season $2017 / 2018$. From the table, it is clear that the water parameters for irrigating the acre vary according to the difference irrigation water requirements per feddan and vary according to different types of crop, irrigation method, and power source, but in general, the water needs of the tomato crop and the required water of the tomato crop are higher than of the wheat crop in the flood irrigation and higher in spray irrigation; as for the cost of raising water for the crop, the cost in the case of the use of electricity and deep water pumps is higher than in the case of diesel and conveyor belts. This is due to the high cost of raising the cubic meter in each of them by a difference of about 25.80 pounds/thousand $\mathrm{m}^{3}$ water.

The cost of rising in the case of irrigation sprinkler is less than that in the case of irrigation by flooding due to the difference in the amount of water quantity of irrigation water required for the crop. According to the method of irrigation, the total costs vary from one crop to another, increasing in the way the source of electricity in the case of the use of diesel and conveyor belts; based on the above statement, it is clear that the relative importance of the costs of raising and distributing water compared to the total variable costs per feddan is different. For wheat, it represents about $36.93 \%$ and $55.71 \%$ of the total variable costs of about 1011.00 and $1290.00 \mathrm{LE} /$ fed respectively, according to the two methods of spray irrigation and flooding irrigation in the case of diesel and conveyor belts, while it reached about $44.19 \%$ and $66.67 \%$ of the total variable costs of 1.07 and 1.38 thousand pounds/fed, respectively, in the flooding irrigation in the case of electricity use.

The total cost of the tomato crop was about $5.53 \%$ and about $8.99 \%$ of the total variable costs, which amounted to about 10.64 and 8.73 thousand pounds/fed respectively, according to the two methods of spray irrigation and flooding irrigation in the case under the use of diesel and conveyor belts and about $6.62 \%$ and $10.76 \%$ of the total variable costs and 8.87 thousand pounds/ fed., respectively, according to the two methods of spray irrigation and irrigation by flooding in the case of the use of electricity.

\section{Productive efficiency indicators and economic to raise and distribute groundwater}

The results are shown in Table 5, representing the indicators of productivity and economic efficiency of the

Table 5 Economic efficiency indicators for raising and distribution of groundwater for field sample crops for tomatoes and wheat during season 2017/2018

\begin{tabular}{|c|c|c|c|c|c|}
\hline \multirow[t]{2}{*}{ Statement } & \multirow[t]{2}{*}{ Unit } & \multicolumn{2}{|l|}{ Tomatoes } & \multicolumn{2}{|l|}{ Wheat } \\
\hline & & Flooding irrigation & Spray irrigation & Flooding irrigation & Spray irrigation \\
\hline Average productivity & & 14.49 & 19.80 & 13.20 & 16.78 \\
\hline Average farm price & Pounds & 1319.00 & 1391.00 & 419.40 & 419.60 \\
\hline Total return & Pounds & 19106.00 & 27546.00 & 5535.00 & 7040.00 \\
\hline \multirow[t]{2}{*}{ Net yield in pound sterling* } & Diesel & 7995.00 & 14523.00 & 2250.00 & 3834.00 \\
\hline & Electricity & 7853.00 & 14414.00 & 2159.00 & 3780.00 \\
\hline \multirow[t]{2}{*}{ Net return on the pound** } & Diesel & 0.72 & 1.12 & 0.69 & 1.20 \\
\hline & Electricity & 0.70 & 1.10 & 0.64 & 1.16 \\
\hline \multirow{2}{*}{$\begin{array}{l}\text { Net return on } 1000 \mathrm{~m}^{3} \text { irrigation } \\
\text { water in pounds***}\end{array}$} & Diesel & 1456.00 & 3417.00 & 639.20 & 1843.00 \\
\hline & Electricity & 1430.00 & 3391.00 & 613.40 & 1817.00 \\
\hline
\end{tabular}

Source: collected and calculated from the questionnaire data for the agricultural season 2017/2018

${ }^{*}$ Net yield in pounds $=$ total return - total costs

**Net return on the pound $=$ net return total costs $\times 100$

***Water net $=$ net yield water quantity per thousand $\mathrm{m}^{3}$ 
lifting and distribution of groundwater from power source in New Valley governorate during the agricultural season $2017 / 2018$ which is the average yield, the total yield, the net yield per feddan, the net yield on the pound, and the net return on $1000 \mathrm{~m}^{3}$ irrigation water, and the table shows the increase in productivity in both crops, wheat and tomatoes, according to the method of irrigation spray, reaching about $16.78 \mathrm{ardab} / \mathrm{fed}$ and $19.80 \mathrm{ton} / \mathrm{fed}$, compared to about $13.20 \mathrm{ardab} / \mathrm{fed}$ and 14.49 ton/fed according to the method of irrigation by flooding; this shows that irrigation spray is more efficient in the case of irrigation by flooding. The table also shows the increase in the total yield in crops, wheat and tomato, according to the method of sprinkler irrigation, reaching about 7.04 pounds/fed and 27.55 thousand pounds/fed, compared to about 5.54 pounds/fed and 19.11 thousand pounds/fed according to the irrigation method. It also shows the total return from spraying irrigation is higher than in the case of irrigation by flooding due to increased productivity; on the other hand, the net yield of both crops was also increased in the case of spraying irrigation from irrigation by flooding. However, in the absence of an impact on the overall yield potential and this effect on the total cost of production, the net return takes the opposite direction of total costs, which means a higher net return in the case of the use of diesel and conveyor belts compared to the same in the case of the use of electricity and deep pumps.

As for the net return on the pound spent in the production of wheat crop, it was shown from the same table above to increase it to a maximum in the case of spraying irrigation with the use of diesel and conveyor belts, which amounted to about 1.19 pounds and decreased to reach below in the case of irrigation flooding in the case of the use of electricity and deep pumps, which amounted to about 0.64 pounds.

In the case of the tomato crop, the net yield on the pound spent in the production of the crop was shown to increase to a maximum in the case of spray irrigation with the use of diesel and conveyor belts, which amounted to about 1.12 pounds and decreased to reach below in the case of flooding irrigation in the case of the use of electricity and deep pumps, about 0.70 pounds. The net return on one thousand $\mathrm{m}^{3}$ irrigation water in the production of wheat crop has been shown from the same table above to increase it to a maximum in the case of spray irrigation with the use of diesel and conveyor belts, which amounted to about 1.84 thousand pounds and decreased below in the case of flooding irrigation in the case of electricity use and the depth pumps reached about 0.613 thousand pounds. In the case of the tomato crop, the net yield per $1000 \mathrm{~m}^{3}$ irrigation water in the production of the crop has been shown to increase to a maximum in the case of spray irrigation with the use of diesel and conveyor belts amounted to about 3.42 thousand pounds and decreased to reach below in the case of flooding irrigation in the case of the use of electricity and pumps depth of about 1.43 thousand pounds.

\section{Discussion}

The results showed that the productivity and economic efficiency indicators for the raising and distribution of groundwater by power source in New Valley governorate during the agricultural season 2017/2018, namely the average productivity, total yield, net revenue per feddan, net return on the pound, and net return on $1000 \mathrm{~m}^{3}$ irrigation water. The increase in productivity in both crops showed wheat and tomatoes according to the method of spraying irrigation, reaching about $16.78 \mathrm{ardab} / \mathrm{fed}$ and 19.80 tons/fed, compared to $13.20 \mathrm{ardab} / \mathrm{fed}$ and 14.49 ton/fed according to the method of irrigation by flooding. This indicates that spraying irrigation is more efficient than a similar case of irrigation of flooding. The table also shows that the total yield of both crops increased, with wheat and tomatoes reaching LE 7.04/feddan, about LE 27.55 thousand/fed, compared to LE 5.54/ fed and 19.11 thousand LE/fed according to the irrigation method. It also shows that the total return from spraying irrigation is higher than in the case of irrigation by flooding due to increased productivity.

The net yield of both crops was also increased in the case of spray irrigation for irrigation by flooding. However, in the absence of an impact on the overall yield potential and this effect on total production costs, the net return takes the opposite direction of total costs, which means a higher net return in the case of the use of diesel and conveyor belts compared to the same in the case of the use of electricity and deep pumps.

As for the net yield on the pound spent in the production of wheat crop, it was shown from the same table above to increase it to a maximum in the case of spray irrigation with the use of diesel and conveyor belts, which amounted to about 1.19 pounds and decreased to reach below in the case of irrigation flooding in the case of the use of electricity and deep pumps about 0.64 pounds. In the case of the tomato crop, the net yield on the pound spent in the production of the crop has been shown to increase up to a maximum in the case of spray irrigation with the use of diesel and conveyor belts, which amounted to about 1.12 pounds and decreased to reach below in the case of irrigation flooding in the case of the use of electricity and deep pumps, about 0.70 pounds

As for the net return on one thousand $\mathrm{m}^{3}$ irrigation water in the production of wheat crop, it has been shown from the same table above to increase it to a maximum in the case of spray irrigation with the use of 
diesel and conveyor belts, which amounted to about 1.84 thousand pounds and decreased to the below in the case of flooding irrigation in the case of electricity use and deep pumps reached about 0.61 thousand pounds. In the case of the tomato crop, the net yield per $1000 \mathrm{~m}^{3}$ irrigation water in the production of the crop has been shown to increase to a maximum in the case of spray irrigation with the use of diesel and conveyor belts amounted to about 3.42 thousand pounds and decreased to reach below in the case of irrigation flooding in the case of the use of electricity and pump depth of about 1.43 thousand pounds.

\section{Conclusion}

It could be concluded that the net return on one thousand $\mathrm{m}^{3}$ irrigation water in the production of wheat crop was increased and the net yield in both crops was increased in the case of spray irrigation instead of irrigation by flooding.

\section{Abbreviations}

fed: Feddan; DRC: Desert Research Center; LE: Egyptian pound

\section{Acknowledgements}

The author(s) are thankful to the all for giving all the vital office to finish the paperwork.

\section{Authors' contributions}

$\mathrm{HE}$ contributed to the review of the paper, aggregation and analysis of data, and the references. EA contributed to the writing of the paper and the references. RE contributed to the review and writing of the paper and aggregation and analysis of data. MM contributed to the analysis of data and writing and reviewing of the paper. All authors read and approved the final manuscript.

\section{Funding}

Not applicable

Availability of data and materials

Not applicable

\section{Competing interest}

The authors declared that they have no competing interests.

\section{Ethics approval and consent to participate}

All authors consented to participate in all parts of the paper.

\section{Consent for publication}

Ok

\section{Author details}

${ }^{1}$ Economics Department, DRC, Cairo, Egypt. ${ }^{2}$ Economics Department, NRC, Dokki, Giza, Egypt. ${ }^{3}$ Field Crops Res. Department, NRC, Dokki, Giza, Egypt.

Received: 6 August 2019 Accepted: 24 September 2019

Published online: 21 November 2019

\section{References}

Hani SARA-S, Salah MAM (2013) Indicators of technological change in the agricultural sector in the New Valley governorate. Egyptian Journal of Agricultural Economics 23(4)

Heba MM (2008) Economic effects for the use of agricultural resources in the new lands. Department of Economic, Legal and Environmental Management Sciences, Institute of Environmental Studies and Research, Ain Shams University, Master of Science
Jalal, Abdel-Fattah Al-Saghir (2003). An analytical study to evaluate some economic development projects agriculture in southern Upper Egypt, Ph.D. Thesis, Department of Agricultural Economics, Faculty of Agriculture, Assiut University.

Abdul Majid, Mousi Abdul Majid (2018). Economic analysis of the productivity of agricultural resources in Wadi Governorate, M.Sc. Thesis, department of Agricultural Economics, Faculty of Agriculture, Benha University

Mohamed, Said Amin El Shishtawy; Hani, Said Abdel Rahman El-Seedla; Mohamed, Abdel Azim Badr and Abdul Majid, Mousi Abdel Majid, (2018). The productivity of agricultural resources in the Valley governorate. Journal of Annals of Agricultural Sciences, Fourth, December.

Osama, Mahmoud Aweida (2005). Economic efficiency of the methods of raising and distribution of groundwater in new lands in Egypt, Egyptian Association of Agricultural Economics, 13th Conference of Agricultural Economists, Contemporary Issues in Egyptian Agriculture, 28-29 Sept.

\section{Publisher's Note}

Springer Nature remains neutral with regard to jurisdictional claims in published maps and institutional affiliations.

\section{Submit your manuscript to a SpringerOpen ${ }^{\circ}$ journal and benefit from:}

- Convenient online submission

- Rigorous peer review

- Open access: articles freely available online

- High visibility within the field

- Retaining the copyright to your article

Submit your next manuscript at $\boldsymbol{\nabla}$ springeropen.com 